Sri Lanka J. Aquat. Sci. 16 (2011): 11-26

\title{
Hook Selectivity of Giant Trevally (Caranx ignobilis) and Nakedbreast Trevally (Carangoides gymnostethus) (Carangidae) caught in the hook-and-line fishery off Negombo, Sri Lanka
}

\author{
U.S. Amarasinghe*, I.U. Wickramaratne and M.J.S. Wijeyaratne \\ Department of Zoology, University of Kelaniya, Kelaniya 11600, \\ Sri Lanka \\ *Corresponding author (zoousa @kln.ac.lk)
}

\begin{abstract}
In the present study, an attempt was made to quantify hook selectivity of two carangid species (Caranx ignobilis and Carangoides gymnostethus) which were predominantly caught in the hook-and-line fishery off Negombo, Sri Lanka. As the length frequency data of $C$. ignobilis and $C$. gymnostethus recorded by hook size were skewed towards the larger fish, a modification of Baranov-Holt method for gillnet selection was employed. For both species there were positive significant relationships $(\mathrm{p}<0.001)$ between the hook size and optimal length while selection range was negatively related to hook size $(\mathrm{p}<0.001)$.
\end{abstract}

Keywords: Carangidae; Hook selectivity; Optimal length; Pelagic fish; Selection Range

\section{Introduction}

Fisheries scientists often rely on the analysis of size/age composition of commercial catches for fish stock assessment. Due to gear selectivity however, the commercial catch samples do not represent actual size or age structure of fish populations. As such, knowledge about the selection characteristics of fishing gear is important for meaningful assessment of fish stocks (Sparre and Venema 1998). Furthermore, as gear selectivity is a function of size of fish in general, quantification of gear selectivity patterns is useful for setting limits for the size at first capture of fish (Pauly 1984). Many studies have shown that length frequency samples derived from angling (Fry 1949), hook-and-line fisheries (Leclere and Power 1980) and longline fisheries (Koike and Kanda 1978; Erzini et al. 1997) exhibit dome-shaped selectivity patterns, somewhat similar to those obtained from gillnets (Baranov 1914; Holt 1963; Hamley 1975). In contrast, Chatwin (1958) reported that the hook selectivity curves of lingcod (Ophiodon elongates) 
were sigmoid and constant above a certain initial age, analogous to trawl selection curves. Similar findings were reported by McCraken (1963) and Sætersdal (1963) for Atlantic cod (Gadus morhua) and haddock (Melanogrannus aeglefinus). Despite these controversial evidences, studies on hook selectivity are scanty and are reported for a few species (e.g., Kanda et al. 1978; Cortez-Zaragoza et al. 1989; Erzini et al. 1997; Shimizu et al. 2000). In the present study, an attempt is made to quantify selectivity characteristics of two species of carangids (Caranx ignobilis (Forsskål, 1775) and Carangoides gymnostethus (Cuvier, 1833), which were dominant in the landings of hook-and-line fishery in Negombo, Sri Lanka.

The fishery

\section{Materials and methods}

There are more than 100 coastal marine fishers who are engaged in hookand-line fishing off Negombo. All hook-and-line fishers operate from small fibre-reinforced plastic (FRP) boats (3.5 m in length) with 15-25 HP outboard engines. The catches are landed between $1430 \mathrm{~h}$ and $1730 \mathrm{~h}$ at the fish landing site in Negombo (Figure 1). The hook-and-line fishers use hook sizes ranging from $8 \mathrm{~mm}$ to $22 \mathrm{~mm}$ depending on the target species (Figure 2). Fishers use penaeid shrimps as baits in the hook-and-line fishery.

\section{Data collection}

Samples were collected from the fish landing site in Negombo from October 1999 to October 2000 to collect length frequency data of dominant species caught in the hook-and-line fishery. More than 70 fish species belonging to 35 families were caught in the hook-and-line fishery off Negombo during the study period. However, the present analysis was performed for the hook-wise data of two species of carangids (Caranx ignobilis and Carangoides gymnostethus), which were predominant in the catches. Length frequency data of these two species (Fork length measured to the nearest $0.5 \mathrm{~cm}$ below its actual length) were recorded from randomly selected boats for 100 hooks of each hook size. 
U.S. Amarasinghe, I.U. Wickramaratne and M.J.S. Wijeyaratne/Sri Lanka J. Aquat. Sci. 16 (2011): 11-26

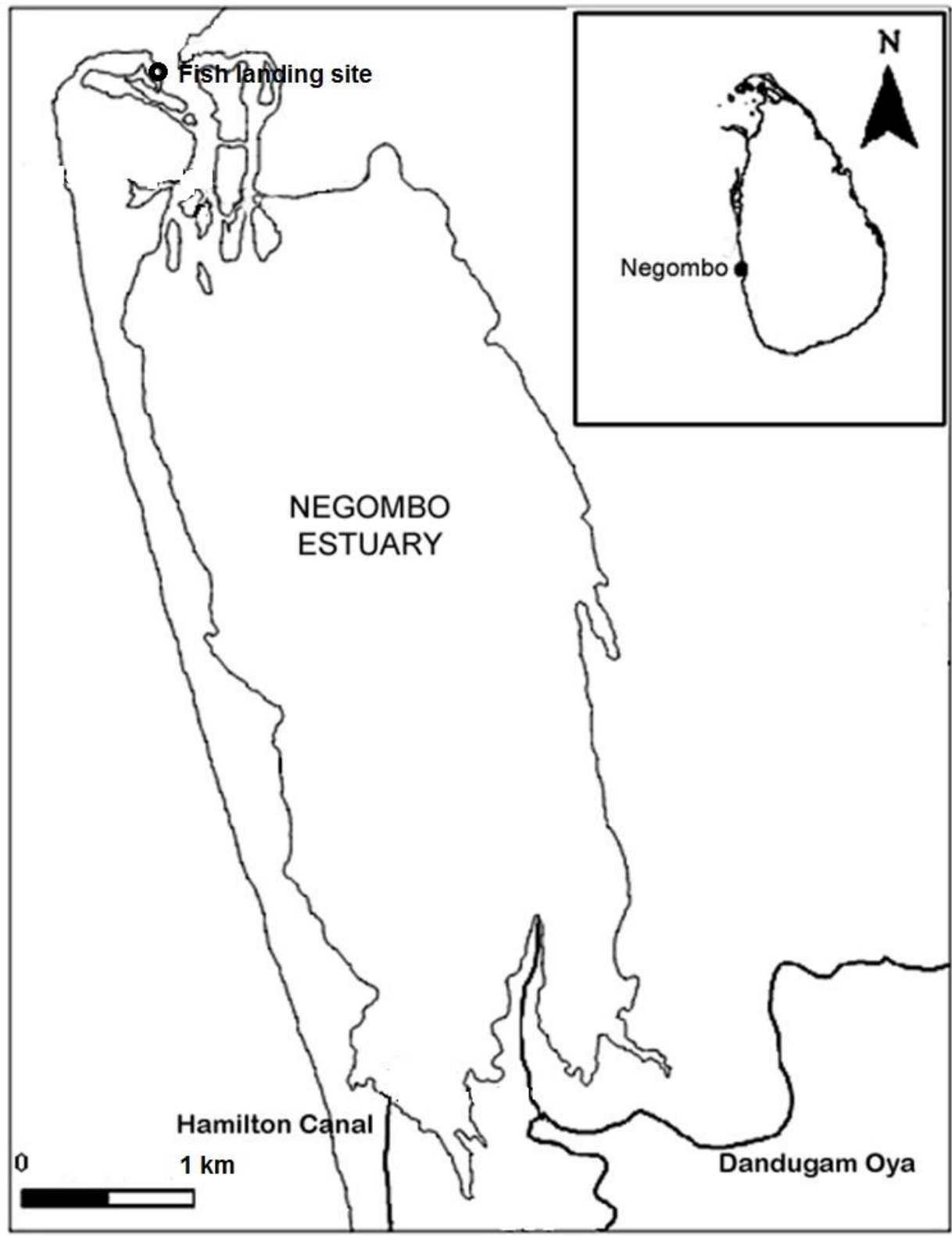

Figure 1. Map of Negombo estuary showing fish landing site where sampling was carried out in the present study, Inset shows the location of Negombo estuary in Sri Lanka. 


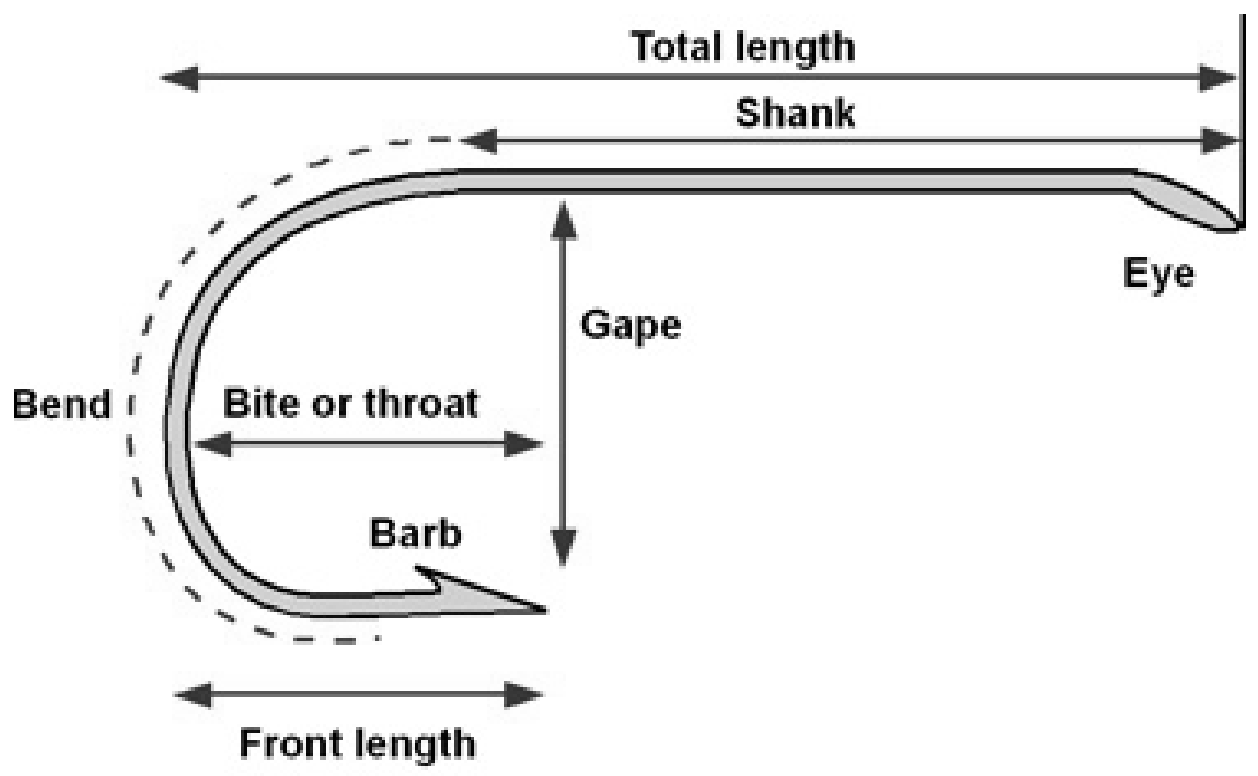

Figure 2. Parts of a hook. Hook size refers to the 'gape' of the hook shown here.

\section{Data analysis}

As the length frequency data of $C$. ignobilis and C. gymnostethus recorded by hook size were apparently skewed towards the larger fish, a modification of Baranov-Holt method for gillnet selection (Baranov 1914; Holt 1963), was employed as explained by Pauly (1984). Selection curves of the two carangid species were estimated separately by comparing the length frequency distributions of each species caught by two adjacent hook sizes.

The logarithm of the mid-point of a length class (L) of fish is linearly related to logarithm of catch ratio $\left(\mathrm{Ln} \frac{\mathrm{C}_{\mathrm{B}}}{\mathrm{C}_{\mathrm{A}}}\right)$ of fish caught in smaller hook size $\mathrm{A}$ and larger hook size $\mathrm{B}$ as follows:

$$
\operatorname{Ln} \frac{\mathrm{C}_{\mathrm{B}}}{\mathrm{C}_{\mathrm{A}}}=\mathrm{a}+\mathrm{b} \operatorname{Ln} \mathrm{L}
$$

The logarithmic value of optimal length of hook size $A\left(\mathrm{~L}_{\text {optA }}\right)$ and hook size $B\left(L_{o p t B}\right)$ were estimated using the following equations.

$$
\begin{aligned}
& \text { Ln } L_{o p t A}=-\frac{2 a^{* A}}{b(A+B)} \\
& \text { Ln } \mathrm{L}_{\mathrm{optB}}=-\frac{2 \mathrm{a} * \mathrm{~A}}{\mathrm{~b}(\mathrm{~A}+\mathrm{B})}
\end{aligned}
$$

The standard deviation (SD) of $\ln \mathrm{L}$ of each hook size was estimated as,

$$
\mathrm{SD}=\sqrt{\frac{2 \mathrm{a}(\mathrm{A}-\mathrm{B})}{\mathrm{b}^{2}(\mathrm{~A}+\mathrm{B})}}
$$


When two estimates of $\mathrm{L}_{\text {opt }}$ for the same hook size were resulted due to comparisons of two length frequency distributions, the mean value was taken as the $\mathrm{L}_{\mathrm{opt}}$ corresponding to the given hook size. The probability of capture for a given Ln L was estimated for each hook size using the following equations.

$$
\begin{aligned}
& P_{A}=\exp \left[-\left\{\frac{\left(\operatorname{Ln} L-L n L_{o p t A}\right)^{2}}{2 S D^{2}}\right\}\right] \\
& P_{B}=\exp \left[-\left\{\frac{\left(\operatorname{Ln} L-L n L_{o p P B}\right)^{2}}{2 S D^{2}}\right\}\right]
\end{aligned}
$$

Probabilities of capture were plotted against L to obtain hook selection curves of the two species for each hook size separately. The relationship between $\mathrm{L}_{\mathrm{opt}}$ and hook size was then determined using linear regression. Selection range defined as one standard deviation on either side of $\mathrm{Ln} \mathrm{L}_{\mathrm{opt}}$ and subsequently converted to anti-logarithm (Cortes-Zeragoza et al. 1989), was also related to hook size.

\section{Results}

During the present study, sufficient numbers of C. ignobilis per 100 hooks were caught by hook sizes $8 \mathrm{~mm}, 9 \mathrm{~mm}, 10 \mathrm{~mm}$ and $11 \mathrm{~mm}$. C. gymnostethus caught in hook sizes of $10 \mathrm{~mm}, 11 \mathrm{~mm}, 12 \mathrm{~mm}$ and $13 \mathrm{~mm}$ were used in the present analysis. As one of the assumptions of the Baranov-Holt method of estimating gillnet selection was that two adjacent mesh sizes would impose similar fishing mortalities, in the modified approach employed in the present study, length frequency distribution of fish in each hook size was used as number of fish per 100 hooks. Length frequency distributions of fish caught in individual hook sizes are shown in Figure 3 for C. ignobilis and in Figure 4 for C. gymnostethus. These length frequency distributions indicate that they are skewed towards large fishes.

The relationships of $\mathrm{Ln}$ catch ratio against $\mathrm{Ln} \mathrm{L}$ for different pairs of hook sizes are shown in Figure 5 for $C$. ignobilis and in Figure 6 for $C$. gymnostethus. The regression equations, significance levels and size ranges used for regression analysis are presented in Table 1. The optimal lengths for different hook sizes and corresponding SD values are given in Table 2. The hook selectivity curves of two species of carangids for different hook sizes, estimated using optimal lengths and SD are shown in Figure 7. For both species there were positive significant relationships $(p<0.001)$ between the hook size and optimal length (Figure 8). Selection range was negatively related to hook size $(\mathrm{p}<0.001)$ in both species (Figure 9). 
16

U.S. Amarasinghe, I.U. Wickramaratne and M.J.S. Wijeyaratne/Sri Lanka J. Aquat. Sci. 16 (2011): 11-26

(a)

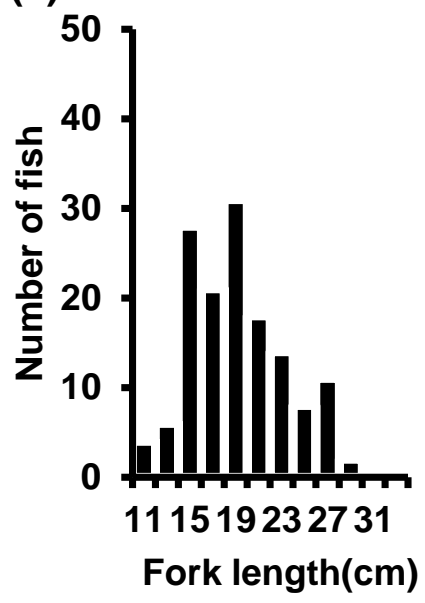

(c)

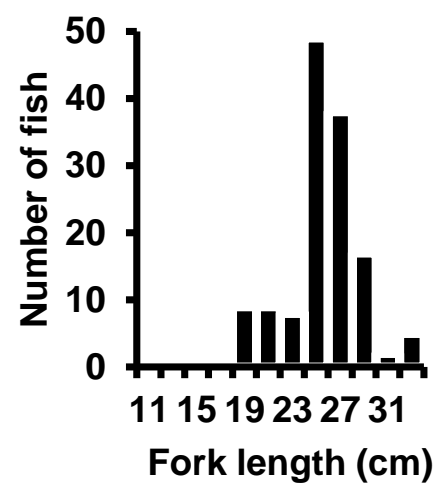

(b)

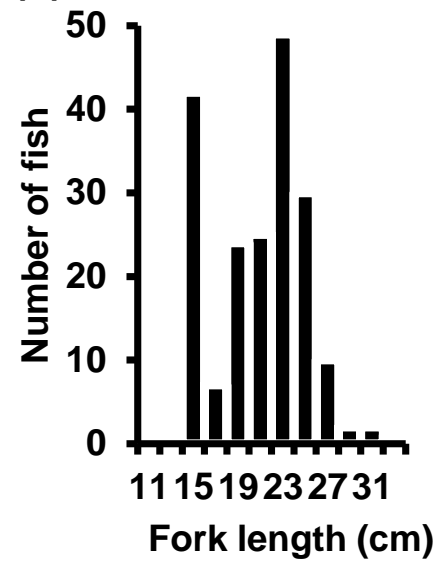

(d)

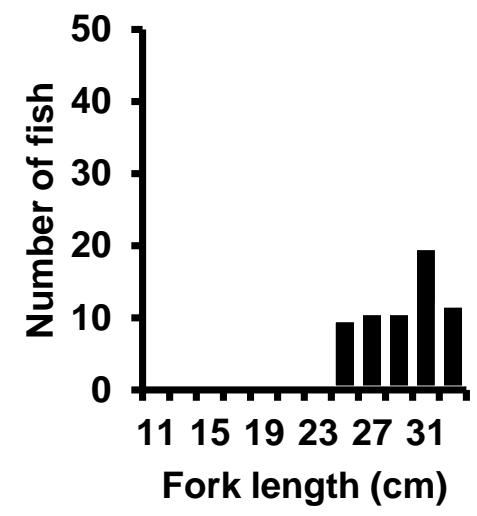

Figure 3. Length frequency distributions of $C$. ignobilis caught in different hook sizes. (a) $8 \mathrm{~mm}$; (b) $9 \mathrm{~mm}$; (c) $10 \mathrm{~mm}$; (d) $11 \mathrm{~mm}$. 
U.S. Amarasinghe, I.U. Wickramaratne and M.J.S. Wijeyaratne/Sri Lanka J. Aquat. Sci. 16 (2011): 11-26

(a)

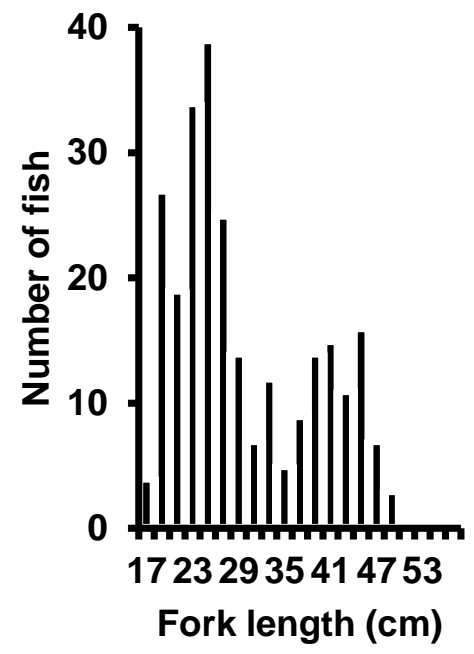

(c)

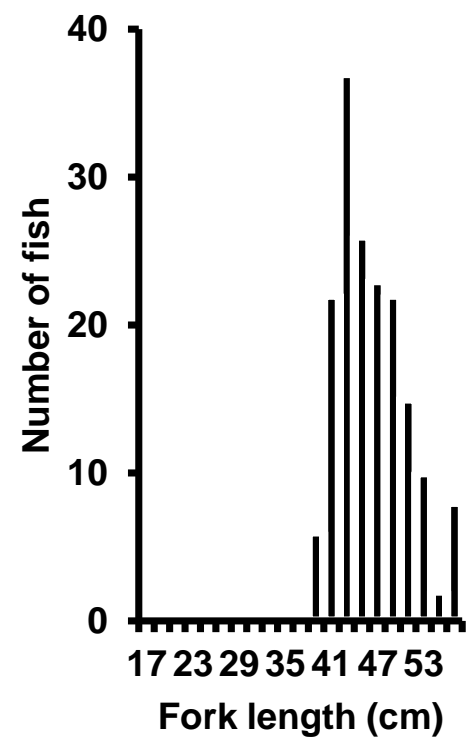

(b)

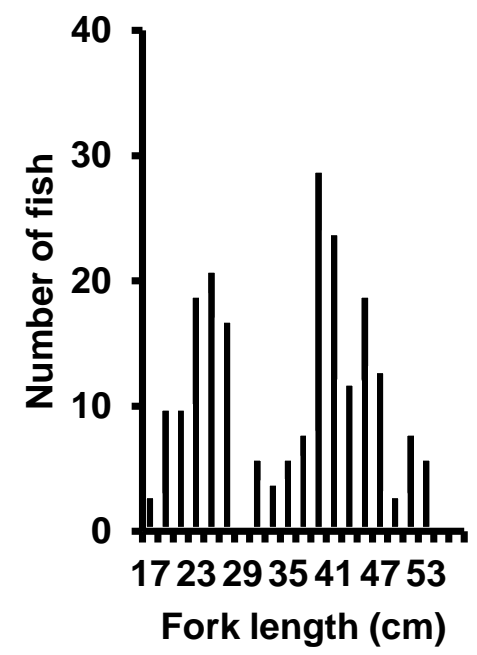

(d)

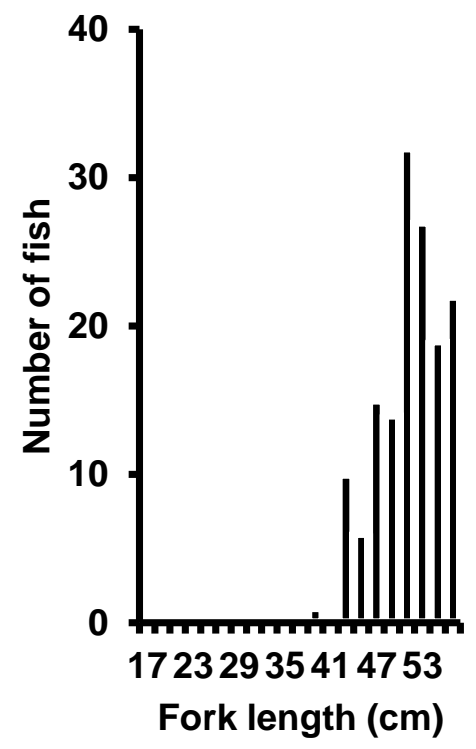

Figure 4. Length frequency distributions of $C$. gymnostethus caught in different hook sizes. (a) $10 \mathrm{~mm}$; (b) $11 \mathrm{~mm}$; (c) $12 \mathrm{~mm}$; (d) $13 \mathrm{~mm}$. 
(2011): 11-26

Table 1. The regression equations, significance levels and size ranges used for regression analysis of the relationship of $\mathrm{Ln}$ catch ratio (Y) against $\mathrm{Ln} \mathrm{L}$ (X) for different pairs of hook sizes. $\mathrm{R}^{2}=$ Coefficient of determination; $\mathrm{r}=$ correlation coefficient; $\mathrm{p}=$ probability level

\begin{tabular}{|c|c|c|c|c|c|}
\hline $\begin{array}{l}\text { Species/Pair of } \\
\text { hook sizes }\end{array}$ & $\begin{array}{l}\text { Regression } \\
\text { equation }\end{array}$ & $\mathrm{R}^{2}$ & $\mathrm{r}$ & $\begin{array}{l}\text { Significance } \\
\text { level }\end{array}$ & $\begin{array}{l}\text { Size } \\
\text { range } \\
(\mathrm{cm})\end{array}$ \\
\hline \multicolumn{6}{|l|}{ C. ignobilis } \\
\hline $9 \mathrm{~mm} / 8 \mathrm{~mm}$ & $\begin{array}{l}Y=6.634 X- \\
19.827\end{array}$ & 0.970 & 0.985 & $\mathrm{p}<0.01$ & $17-25$ \\
\hline $10 \mathrm{~mm} / 9 \mathrm{~mm}$ & $\begin{array}{l}Y=5.487 X- \\
17.570\end{array}$ & 0.555 & 0.745 & $\mathrm{p}<0.05$ & $19-33$ \\
\hline $11 \mathrm{~mm} / 10 \mathrm{~mm}$ & $\begin{array}{l}Y=12.265 X- \\
41.259\end{array}$ & 0.702 & 0.838 & $\mathrm{p}<0.10^{*}$ & $25-33$ \\
\hline \multicolumn{6}{|l|}{ C. gymnostethus } \\
\hline $11 \mathrm{~mm} / 10 \mathrm{~mm}$ & $\begin{array}{l}Y=1.213 X- \\
4.327\end{array}$ & 0.560 & 0.748 & $\mathrm{p}<0.01$ & $17-47$ \\
\hline $12 \mathrm{~mm} / 11 \mathrm{~mm}$ & $\begin{array}{l}Y=8.359 X- \\
31.363\end{array}$ & 0.536 & 0.732 & $\mathrm{p}<0.10^{\ddagger}$ & $39-51$ \\
\hline $13 \mathrm{~mm} / 12 \mathrm{~mm}$ & $\begin{array}{l}Y=10.240 X- \\
39.785\end{array}$ & 0.841 & 0.917 & $\mathrm{p}<0.001$ & $39-57$ \\
\hline
\end{tabular}

$\$$ Not significant at 0.05 probability level

Table 2. The optimal lengths ( $\mathrm{L}_{\mathrm{opt}}$ ) for different hook sizes, standard deviations (SD) and selection ranges of $C$. ignobilis and C. gymnostethus. Here SD values are for the distribution of $\mathrm{Ln} \mathrm{L}$.

\begin{tabular}{llll}
\hline Species/Hook size $(\mathrm{mm})$ & $\mathrm{L}_{\text {opt }}(\mathrm{cm})$ & $\mathrm{SD}(\mathrm{cm})$ & $\begin{array}{l}\text { Selection range } \\
(\mathrm{cm})\end{array}$ \\
\hline C. ignobilis & & & \\
$8 \mathrm{~mm}$ & 16.7 & 0.230 & $15.1-18.2$ \\
$9 \mathrm{~mm}$ & 22.4 & 0.240 & $20.8-24.0$ \\
$10 \mathrm{~mm}$ & 27.1 & 0.205 & $25.6-28.6$ \\
$11 \mathrm{~mm}$ & 33.9 & 0.162 & $32.5-35.3$ \\
C. gymnostethus & & & \\
$10 \mathrm{~mm}$ & 29.9 & 0.529 & $27.0-32.8$ \\
$11 \mathrm{~mm}$ & 39.1 & 0.363 & $37.0-41.2$ \\
$12 \mathrm{~mm}$ & 45.9 & 0.186 & $44.5-47.4$ \\
$13 \mathrm{~mm}$ & 56.9 & 0.174 & $55.4-58.3$ \\
\hline
\end{tabular}


U.S. Amarasinghe, I.U. Wickramaratne and M.J.S. Wijeyaratne/ Sri Lanka J. Aquat. Sci. 16 (2011): 11-26
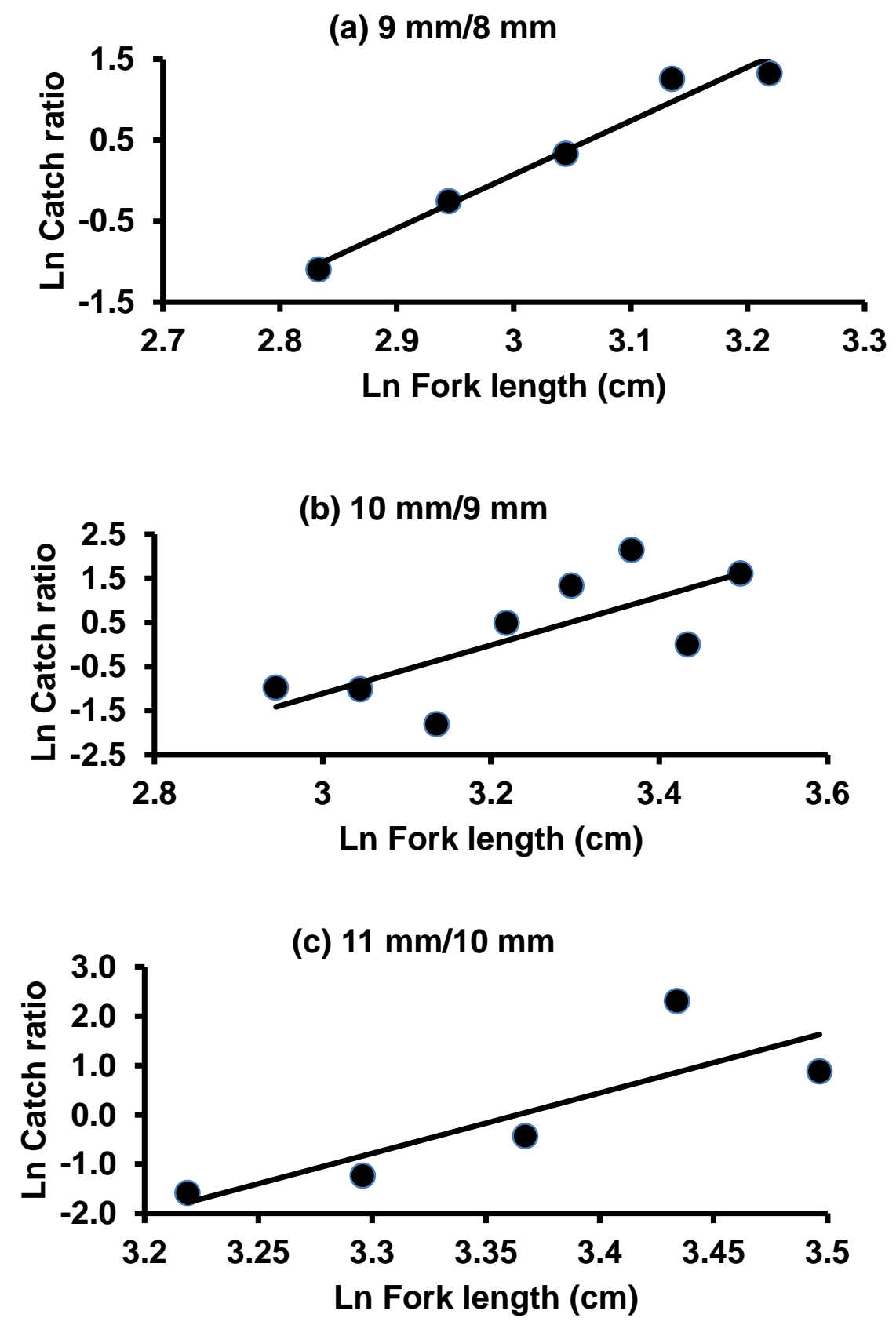

Figure 5. The relationships of $\mathrm{Ln}$ catch ratio against $\mathrm{Ln} \mathrm{L}$ for different pairs of hook sizes for $C$. ignobilis. 

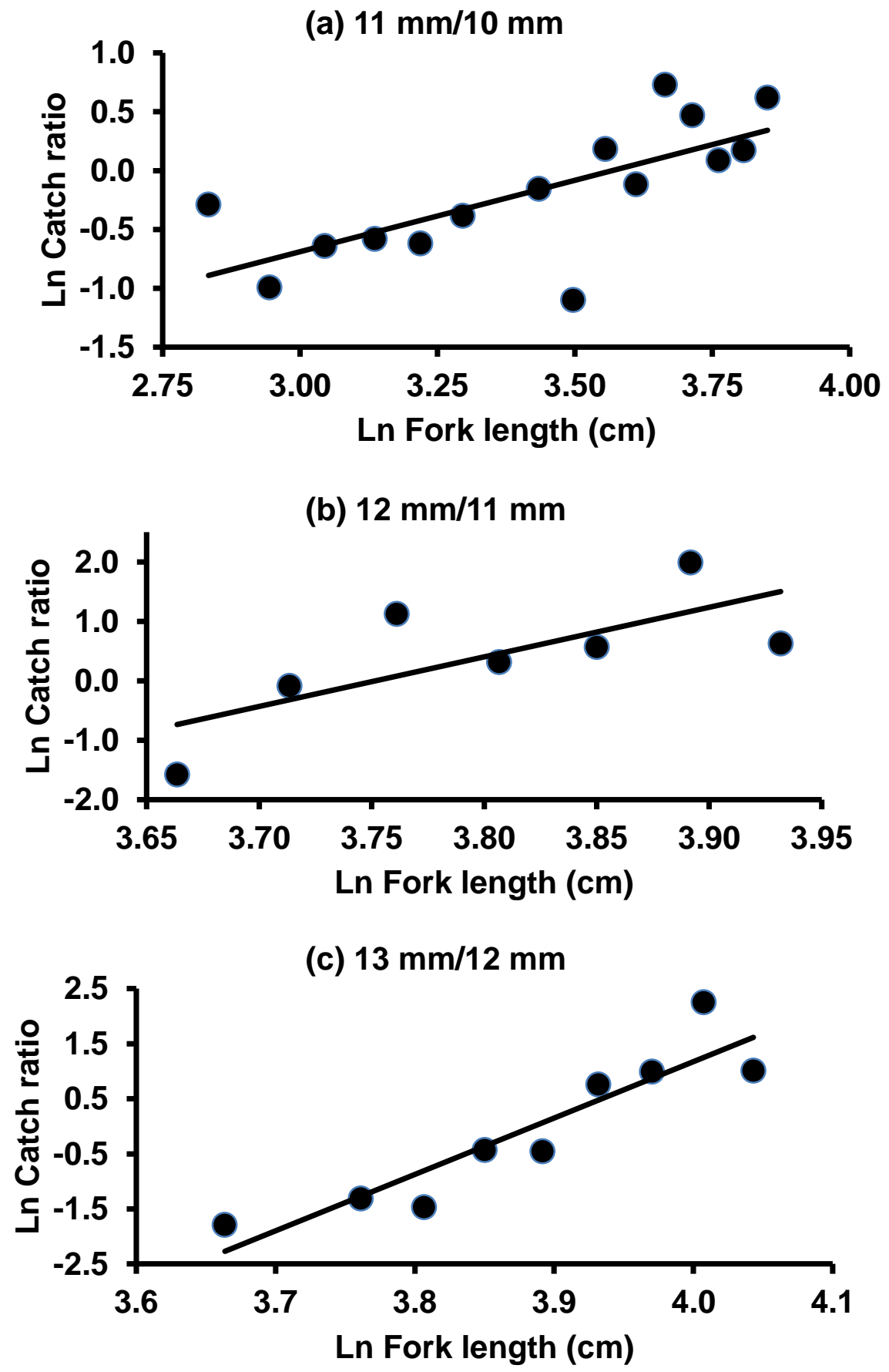

Figure 6. The relationships of $\mathrm{Ln}$ catch ratio against $\mathrm{Ln} \mathrm{L}$ for different pairs of hook sizes for C. gymnostethus. 
U.S. Amarasinghe, I.U. Wickramaratne and M.J.S. Wijeyaratne/Sri Lanka J. Aquat. Sci. 16 (2011): 11-26
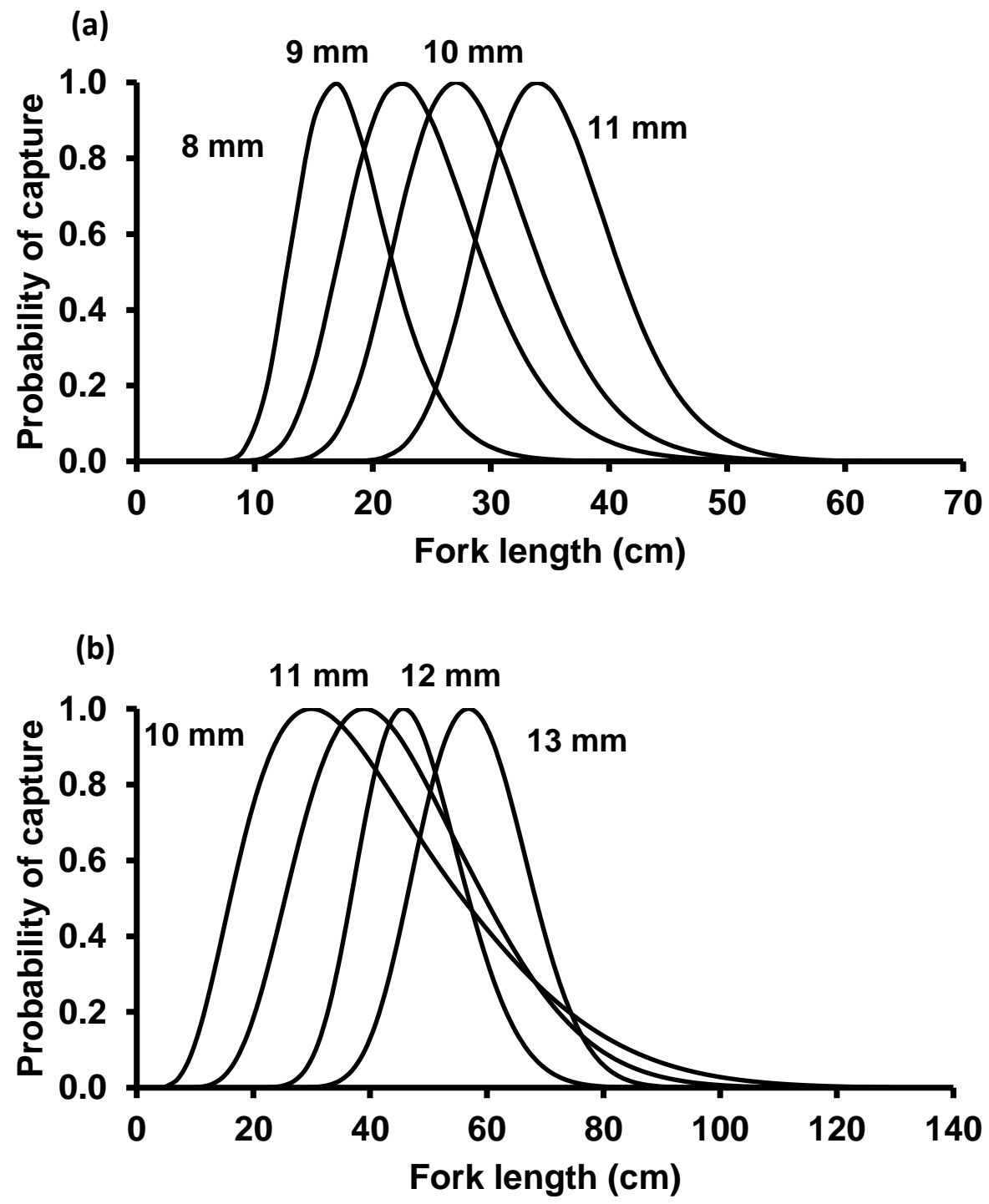

Figure 7. The hook selectivity curves of two species of carangids for different hook sizes. (a) C. ignobilis; (b) C. gymnostethus. 
(a)

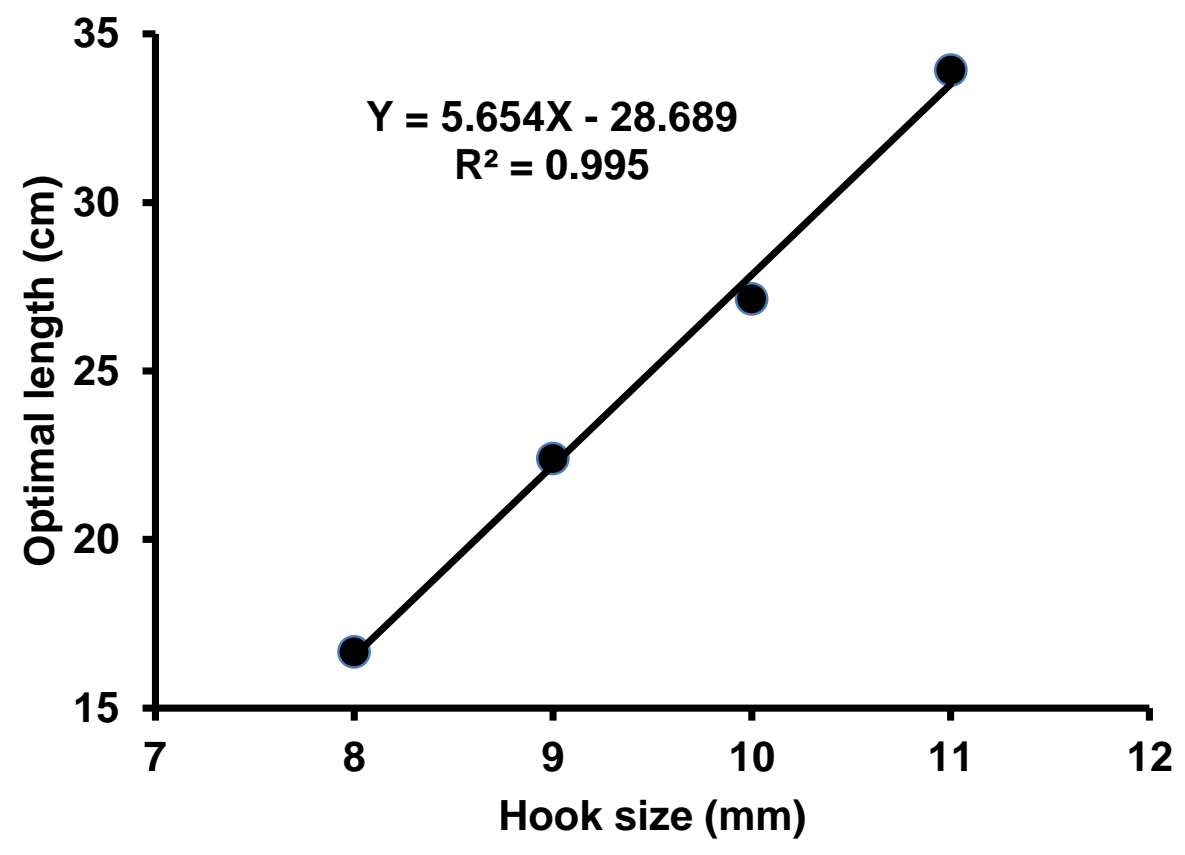

(b)

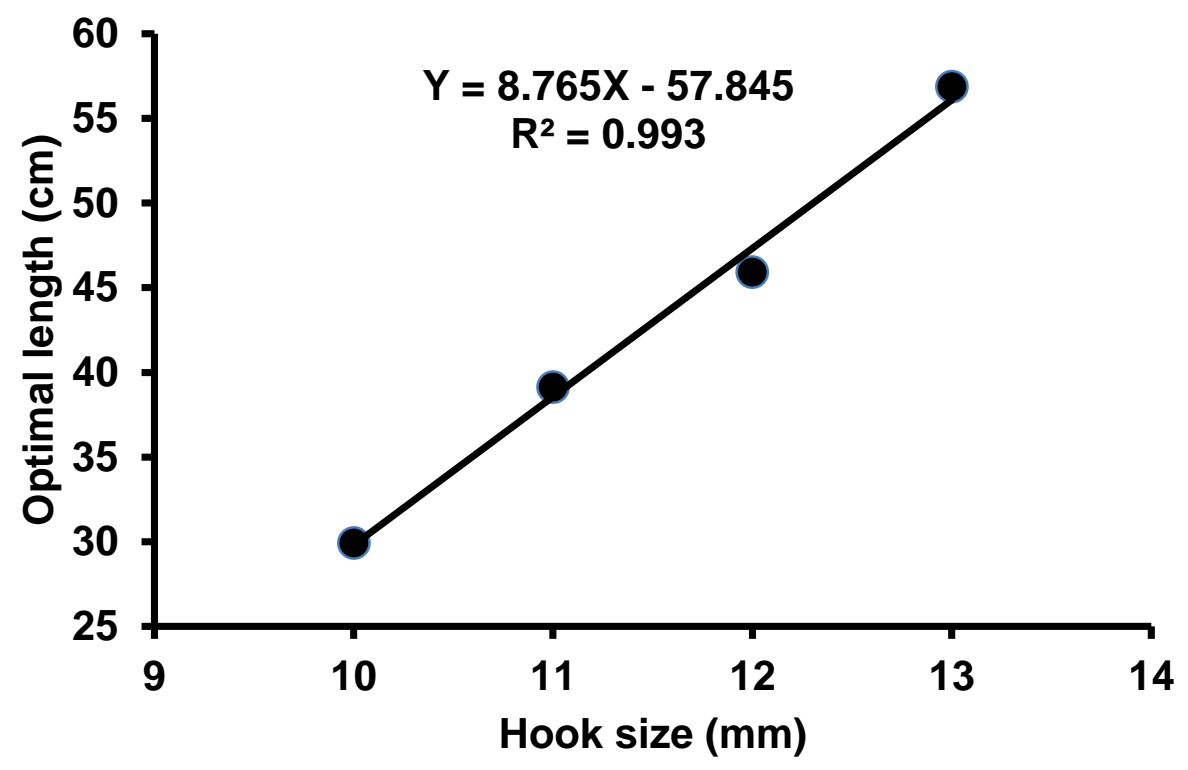

Figure 8. Relationships between the hook size and optimal length. (a) $C$. ignobilis; (b) C. gymnostethus. 
U.S. Amarasinghe, I.U. Wickramaratne and M.J.S. Wijeyaratne/ Sri Lanka J. Aquat. Sci. 16 (2011): 11-26

(a)

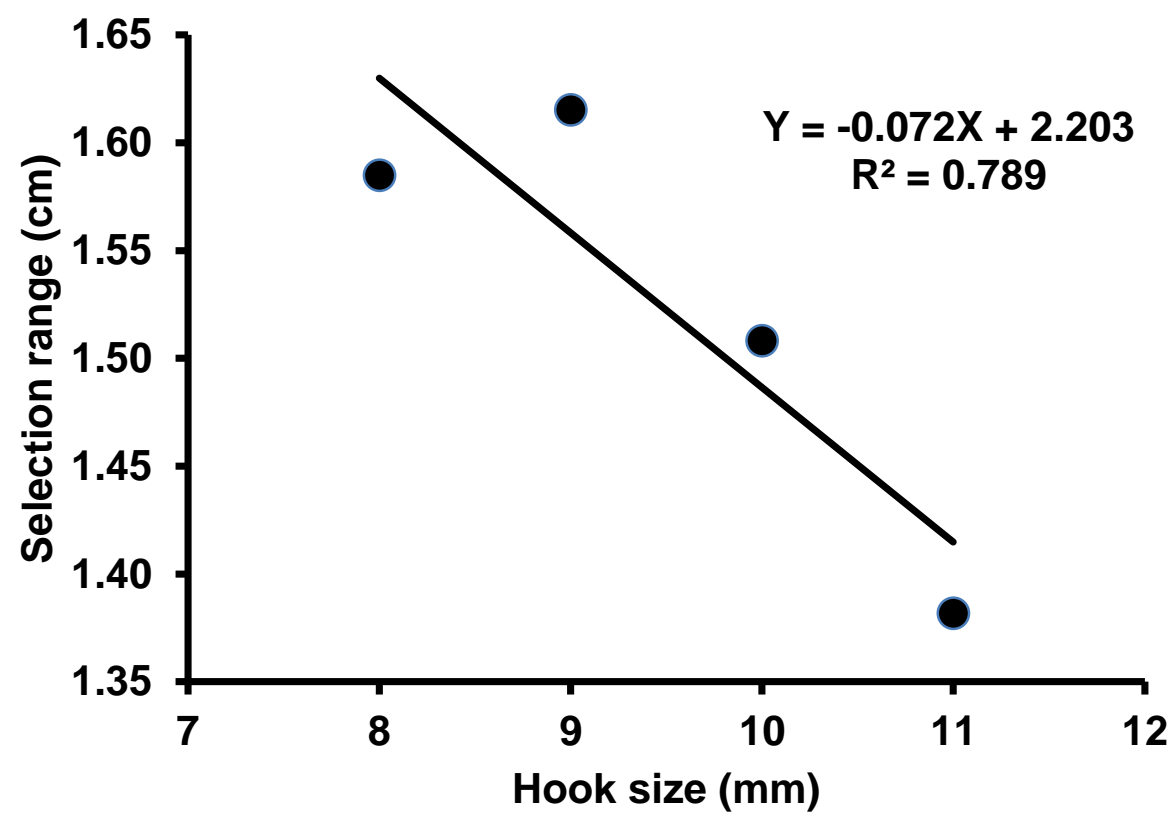

(b)

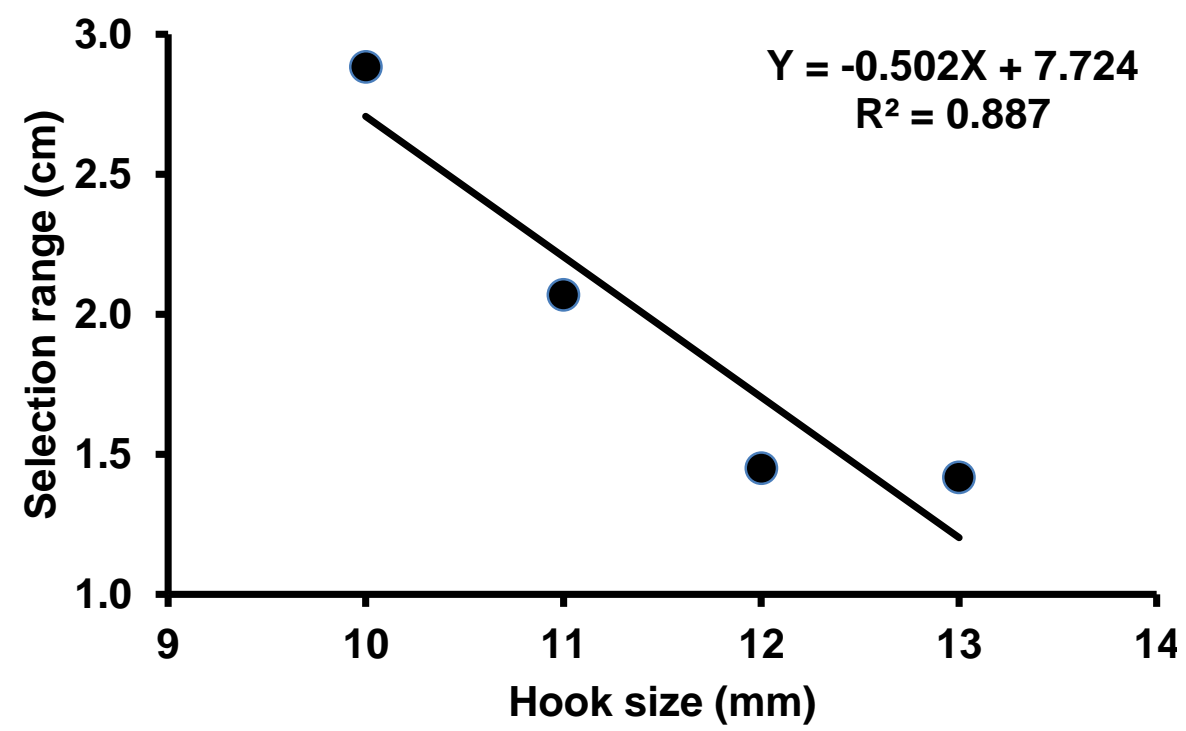

Figure 9. Relationships between the hook size and Selection range. (a) $C$. ignobilis; (b) C. gymnostethus.

\section{Discussion}


According to www.fishbase.org, the maximum recorded length of $C$. ignobilis (170 cm total length) is much higher than that of $C$. gymnostethus (90 $\mathrm{cm}$ total length (Froese and Pauly 2010). However, during the present study, the maximum lengths recorded were $33 \mathrm{~cm}$ fork length for $C$. ignobilis and $57 \mathrm{~cm}$ fork length for $C$. gymnostethus. This must be due to the reasons inter alia, low abundance or absence of large specimens in the fishing area/fishing depth, ability of large fish to avoid hooks and size-dependent differences in effectiveness of the bait type used.

The selection characteristics of $C$. ignobilis and C. gymnostethus quantified in the present study indicated that skewed unimodal selection curves for different hook sizes conform to the most widely used principle of geometric similarity in gillnet selectivity models. Geometric similarity principle states that all fish of the same species, which are geometrically similar, are caught in the geometrically similar fishing gear producing similar selection curves (Baranov 1948; Hamley 1975). These findings were in agreement with the observations made by Cortes-Zeragoza et al. (1989) for yellowfin tuna, Thunnus albacores caught off Darigayos Cove, Northern Luzon, Philippines. Shimizu et al. (2000) also reported unimodal skewed size selectivity of angling gear for masu salmon (Oncorhynchus masou). However, several studies indicated that hook selection conformed to sigmoid trawl-type selection ogives (Ralston 1982; Peixer and Petrere 2007). Furthermore, some studies indicated that the catch size distributions for the different hook sizes for each species were highly overlapping, with little or no evidence of differences in size selectivity (Erzini et al. 1999).

In the present analysis, selection range of both carangid species decreased with increasing hook size, in contrast to those reported by Ralston (1982) and Cortes-Zeragoza et al. (1989). The inconsistencies of hook selectivity were said to be attributed to several factors such as scarcity of large fishes and fish behaviour. As such, further studies are needed to investigate the reasons for differences in hook selectivity patterns of fish.

As optimal lengths of the two carangid species are linearly related to hook size, the results of the present analysis are useful to regulate the size at fist capture of fish. However, these relationships (Figure 8) are valid only for the size ranges of fish used for determining the relationships. It was also observed that over 70 fish species were caught in the hook-and-line fishery off Negombo during the study period. Reduction of by-catch is generally a major concern in hook-and-line and longline fisheries and several studies are reported to introduce circle hooks instead of ' $\mathrm{J}$ ' shaped kooks (Aneesh Kumar et al. 2013; Ferrari and Kotas 2013). As the hook-and-line fishery off Negombo is exclusively dependent on ' $J$ ' shaped hooks, studies should also be directed towards the investigation of ecological impacts of this fishery. 
U.S. Amarasinghe, I.U. Wickramaratne and M.J.S. Wijeyaratne/Sri Lanka J. Aquat. Sci. 16

(2011): 11-26

\section{References}

Aneesh Kumar, K.V., P.S. Khanolkar, P. Pravin, V.R. Madhu and B. Meenakumari 2013.

Effect of hook design on longline catches in Lakshadweep Sea, India. Indian Journal of Fisheries 60(1): 21-27.

Baranov, F.I. 1914.

The capture of fish by gillnets. Mater Pozonsniyu Russian Rybolovsta 3(6): 56-99 (in Russian). Translated version in 1976. Selected Works on Fishing Gear. Vol. I. Commercial Fishing Techniques. Israel Programme for Scientific Translations, Jerusalem. Baranov, F.I. 1948.

Theory and assessment of fishing gear. Chapter 7. Theory of fishing with gillnets. Pishchepromizdat, Moscow. (Translated from Russian by the Ontario Department of Lands and Forests. Ontario, Canada).

Chatwin, B. M. 1958.

Mortality rates and estimates of theoretical yield in relation to minimum commercial size of lingcod (Ophiodon elongatus) from the Strait of Georgia, British Columbia. Journal of Fisheries Research Board of Canada 15: 831-849.

Cortez-Zaragoza, E., P. Dalzell and D. Pauly 1989.

Hook selectivity of yellowfin tuna (Thunnus albacores) caught off Dariyagos Cove, La Union, Philippines. Journal of Applied Ichthyology 5(1): 12-17.

Erzini, K., J.M.S. Gonçalves, L. Bentes and P.G. Lino 1997.

Fish mouth dimensions and size selectivity in a Portuguese longline fishery. Journal of Applied Ichthyology 13: 41-44.

Erzini, K., J.M.S. Gonçalves, L. Bentes, P.J. Lino and J. Ribeiro 1999.

Catch composition, catch rates and size selectivity of three long-line methods in the Algarve (Southern Portugal). Boletín Instituto Español de Oceanografía15 (1-4): 313-323.

Ferrari, L.D. and J.E. Kotas 2013.

Hook selectivity as a mitigating measure in the catches of the stingray Pteroplatytrygon violacea (Elasmobranchii, Dasyatidae) (Bonaparte, 1832). Journal of Applied Ichthyology 29(4): 769-774. doi: $10.1111 /$ jai.12182

Froese, R. and D. Pauly (eds) 2010.

FishBase. World Wide Web electronic publication. http//:www. fishbase.org [version 05/2010] (visited in August 2010).

Fry, F.F.J. 1949.

Statistics of a lake trout fishery. Biometrics 5: 27-67.

Hamley, J.M. 1975.

Review of Gill net Selectivity. Journal of Fisheries Research Board of Canada 32(11): 1943-1969. 
(2011): 11-26

Holt, S.J. 1963.

A method for determining gear selectivity and its application. International Commission for Northwest Atlantic Fisheries (Special Publication) 5: 106-115.

Kanda, K., A. Koike, S. Taeuchi and M. Ogura 1978.

Selectivity of the hook for mackerel, Scomber japonicus Houttuyn, pole fishing. Fisheries Journal of Tokyo University 64: 109-114.

Koike, A. and K. Kanda 1978.

Selectivity of the hook of pond smelt (Hypomesus olidus). Fisheries Journal of Tokyo University 64: 115-123.

Leclere, J. and G. Power 1980.

Selectivity of fly-fishing, spinning and gillnet for brook charr and ouananiche in a large northern Quebec river. Environmental Biology of Fishes 5: 181-184.

McCracken, F.D. 1963.

Selection by codend meshes and hook of cod, haddock, flatfish and red fish. In The Selectivity of Fishing Gear. International Commission for Northwest Atlantic Fisheries, Special Publication No. 5: 131-155.

Pauly, D. 1984.

Fish population dynemics in tropical waters: A Manual for use with Progammable Calculators. ICLARM Studies and Reviewers No. 8, Manila, Philippines. 325 p.

Peixer, J. and Petrere Jr., M. 2007.

Hook selectivity of the Pacu Piaractus mesopotamicus (Holmberg, 1887) in the Pantanal, the state of Mato Grosso do Sul, Brazil. Brazilian Journal of Biology 67(2): 339-345.

Ralston, S. 1982.

Influence of hook size in the Hawaiian deep-sea handline fishery. Canadian Journal of Fisheries and Aquatic Science 39: 1297 - 1382.

Sætersdal, G. 1963.

Selectivity of Long Lines. In The Selectivity of Fishing Gear. International Commission for the Northwest Atlantic Fisheries, Special Publication No., 5, pp. 189-192.

Shimizu, S., Y. Fujimori, T. Miura and K. Nashimoto 2000.

Size selectivity curves of Sode hooks for Masu Salmon derived from the stochastic model of hooking mechanism. Bulletin of the Faculty of Fisheries Hokkaido University 51(1): 13-23.

Sparre, P. and S.C. Venema 1998.

Introduction to tropical fish stock assessment. Part 1. Manual. FAO Fisheries Technical Paper No. 306/1 (Rev. 2): 407 pp. 